\title{
"He Only Talks": Arruntius and the Formation of Interpretive Communities in Ben Jonson's Sejanus
}

Arruntius is an important character in political readings of Ben Jonson's Sejanus His Fall (1605). ${ }^{1}$ He appears frequently in the play, performing for the audience a close reading of the speeches and actions of the other characters. At times, Arruntius appears to act as "Jonson's spokesperson." ${ }^{2}$ In their assessment of the character, critics are remarkably consistent, and they tend to make the following observations about him: first, he is a Stoic; second, he is all talk and no action. While recognizing that Arruntius is a "figure of moral integrity," 3 critics are skeptical of his habit of articulating his criticism in asides from the relative safety of the stage's periphery. Thus, it has been suggested that Arruntius lacks Roman virtù. His physical displacement on the stage is interpreted as an extension of his political inaction. Along with the rest of the Germanicans, Arruntius is so oppressed by Tiberius and Sejanus's network of spies or "clients" that his "only outlet is speech."

The Ben Jonson Journal 18.1 (2011): 126-140

DOI: $10.3366 /$ bjj.2011.0011

(C) Edinburgh University Press

www.eupjournals.com/bjj 
In this essay I argue that the portrait of Arruntius as a passive Stoic is injudicious, and then I develop a new reading of Jonson's depiction of Arruntius based on the textual evidence from both the quarto and folio editions of the play. The essay proceeds in three sections. In the first section, I question the commonly held view regarding Arruntius's Stoicism: is Arruntius an exemplary Stoic when he can be seen fulminating repeatedly against Tiberius, Sejanus, and even the gods? In the second section, I focus on Arruntius's speeches during the trial of Silius in act 3. The critical perception that Arruntius comments from the margins of the stage is reinforced by modern editions which designate as many as twenty-six of Arruntius's speeches in act 3 as asides. A collation of the quarto and folio texts shows that the count is inflated. Furthermore, in the original texts, Arruntius's most pointed criticism is not typographically distinguished as asides: they are printed as regular speech. Based on this finding, I reconsider the function of Arruntius's invective by asking whether in substance and delivery, his remarks upon the legal proceedings in act 3 constitute a form of parrhesia (or frank speech). In the final section, the focus becomes more theoretical: what is the significance of the public nature of Arruntius's commentary? How does Arruntius involve others in his legal analysis and how does the group of commentators form a critically engaged public? Because readings of the play's philosophical and political significance seem to hinge upon the interpretation of this one character, and because critical interpretations of Jonson's political imagination seem to depend so heavily on this play, I believe it is doubly important for us to reevaluate the case of "old Arruntius" who "only talks" $(2.219,2.299))^{5}$

\section{Reevaluating Arruntius's Stoicism}

As one of the first critics to pay attention to Arruntius, Marvin Vawter set the tone for subsequent readings of the character. Vawter argues that the Germanicans, including Arruntius, inadvertently engineer their own destruction. Because they retire from Roman political life, and because they refuse to attack Tiberius 
or Sejanus, the Germanicans render themselves defenseless against Sejanus and Tiberius's persecution. ${ }^{6}$ Vawter argues that under Sejanus's malignant influence, Tiberius, envious to begin with, becomes even more insecure about his power. Through imprisonments, assassinations, and executions, Tiberius attempts to annihilate the Germanicans. As a result of Tiberius's capricious policies, fear and misinformation spread through Roman society.

Closer examination of the text generates contradictory evidence regarding Arruntius's Stoicism. If Stoicism entails retirement from the political realm and mastery over one's passions, then the character who most exemplifies this political-philosophical attitude is Lepidus, not Arruntius. In the play, Arruntius asks Lepidus by what "arts" he has managed to survive to his advanced age. Lepidus replies

Arts, Arruntius?

None, but the plaine, and passive fortitude,

To suffer, and be silent; never stretch

These armes, against the torrent; live at home,

With my owne thoughts, and innocence about me,

Not tempting the wolves iawes: these are my artes.

In this conversation, Jonson casts Arruntius in the role of the student seeking enlightenment and Lepidus as the teacher with the answers. Compared to Lepidus, Arruntius is a novice Stoicif that. Arruntius's skeptical reply to Lepidus's speech reinforces this impression: "I would begin to studie 'hem, if I thought / They would secure me"; however, in Rome, "no place ... is free ... from some one kind of cruelty" (4.299-300, 312-14).

In the following passage from act 4, Arruntius appears to lose control over his reason. First, he cries out for divine intervention. Next, he indicts the gods for their inaction. Finally, he commits an act of religious apostasy: he rejects the protection of Jove for that of "fortune":

Still, do'st thou suffer, heav'n? will no flame, No heat of sinne, make thy iust wrath to boile In thy distemp'red bosome, and ore-flow

The pitchy blazes of impietie, 
Kindled beneath thy throne? ...

Jove, will nothing wake thee?

Well! Snore on, dreaming gods:

And let this last of that proud Giant-race,

Heave mountayne upon mountayne, 'gainst your state-

Be good unto me, fortune, and you powers

Whom I, expostulating, have profan'd;

In this apocalyptic portrait of Roman society, the repetition of "heat" (flame, boile, kindled), the passions associated with such heat (sinne, wrath, distempter, and ore-flow), the heaping of rhetorical questions, and the pounding of the words "mountayne upon mountayne" aptly express Arruntius's pent-up rage. It is one of the many lapses in moderation, rhetorical and emotional, which he displays in the play. Given his railing against the gods, and his claim to be a follower of "fortune," it is hard to accept the classification of Arruntius as a Stoic.

When Jonson edited the text for inclusion in the folio of 1616, he inserted two lines into a scene in act 4 to emphasize Arruntius's volatile temper. The emendation usually goes unremarked, but it is significant for the present discussion. The scene opens with Laco, Pomponius, Minutius, and Terentius speaking among themselves about the worsening political climate in Rome. They are overheard by Lepidus and Arruntius. Pomponius states that in Rome, "[m]ore altars smoke to him [Sejanus], then all the gods" (4.433). Arruntius quips, "[t]hat the deare smoke would choke him, / That would I more" (4.434-35), to which Lepidus replies "[p]eace, good Arruntius" (4.435). Herford and Simpson observe in the textual note to Sejanus that the majority of Jonson's emendations take the form of "minutiae of spelling, punctuation, and wrong type," making the addition of those two lines a significant textual event (p. 335).

The emendation emphasizes the teacher-student relationship of Lepidus and Arruntius. Furthermore, Lepidus's gentle rebuke of Arruntius harkens back to Sabinus's restraint of Arruntius in the first act. In this act, Arruntius proposes swift retaliation against 
Sejanus: "[w]e that know the evil, / Should hunt the Palacerattes, or give them bane" (1.426-27). Sabinus, however, perceiving Sejanus's friendship with Tiberius, cautions against such action:

We must abide our opportunity:

And practise what is fit, as what is needfull.

"It is not safe $t$ 'enforce a soverainge's eare:

"Princes heare well, if they at all will heare.

(1.431-34)

As the scene makes clear, Sabinus and Lepidus view their friend's hot temper as a liability to himself and, possibly, to the entire Germanican faction. Unlike Arruntius, Sabinus is circumspect with his words and vigilant about the potential presence of spies. Sejanus's spies-Latiaris, Rufus, and Opsius-go to elaborate lengths to trick Sabinus into criticizing Tiberius (3.3). The difference between Arruntius and Sabinus's temperament is also manifested in their respective language. In the passage quoted above, Sabinus's lines are structurally elegant. The caesura at 1.432 emphasizes the internal balance of the line, enacting aurally the sense of his argument about "practis[ing] what is fit." The second part of the rhyming couplet at the end of the passage is typographically marked (through the use of quotation marks) as a sententia: the symbol replicates the sense of Sabinus's message about prudence.

At the end of the play, Arruntius's outlook undergoes a sharp reversal. His speech reflects a pessimistic view regarding human agency. In the final scene, Arruntius appears to abandon the possibility of effective action. After learning that the Roman crowd, in a Bacchic frenzy, has shredded Sejanus's body to pieces, and that Macro has brutally murdered Sejanus's children, Arruntius condemns both the political life (vita activa) and the faculty of sympathy, declaring "he that lends you pity is not wise" (5.897). In this moment, Arruntius sounds like an exemplary Stoic. This transformation, however, has taken five acts to complete.

In depicting a transformation in Arruntius's philosophical outlook, Jonson takes his cue, perhaps, from Tacitus. After the downfall of Sejanus, Macro accuses Arruntius and a number of others of "many crimes." Because Arruntius "could not endure 
wickedness," he commits suicide on the eve of his trial, speaking the following words just before his death:

... he had lived long enough... he had among so many vain mockeries and perils prolonged his heavy and careful old age... True it is, he might linger out during the short time the Prince [Tiberius] hath to live: but how should he escape the young Prince [i.e. Caligula] which is to come ... I foresee (said he) a heavier servitude; and therefore I will fly as well from that which is already past, as that which is at hand.?

Historically, many years pass before Arruntius despairs of life. For the purpose of dramatic tension, Jonson accelerates the action. It is one of the instances of Jonson's breaches of the "strict laws of time," for which he apologizes in the preface to the play ("To the Readers," p. 350).

To summarize, while they share a common republican vision, the Germanicans are not interchangeable characters. It is difficult to sustain the view that all of them are Stoics. Arruntius initially questions the value of Stoic philosophy, but comes to embrace it after experiencing Sejanus and Tiberius's reign of terror. The play is a tragedy in a double sense. Many innocent characters die. The survivors (like Arruntius) are irrevocably changed-and not for the better. In Arruntius, Jonson encourages the audience to reflect more broadly on the burden of living under a tyrannical ruler.

\section{Editing Arruntius's Speeches}

In the quarto of 1605 and the folio of $1616,{ }^{8}$ Arruntius speaks eight asides-and only eight-in the entire act. ${ }^{9}$ Both texts use parentheses to mark asides. Modern editors do not always preserve the original number of asides as the following tabulation shows (see Table 1).

As a result of editorial intervention, the modern text of Sejanus appears to substantiate the established scholarly claims about Arruntius. The convergence of critical opinion and editorial practice may be accidental; nonetheless, it potentially causes the 
Table 1. An examination of Arruntius's asides in act 3 in select modern editions of Sejanus.

\begin{tabular}{lllc}
\hline Year & Editor & Publisher & No. of Asides \\
\hline 1954 & Herford and Simpson $^{10}$ & Oxford UP & 8 \\
1965 & Jonas A. Barish $^{11}$ & Yale UP & 23 \\
1989 & Johanna Procter $^{12}$ & Cambridge UP & 13 \\
1990 & Philip J. Ayres $^{13}$ & Manchester UP & 22 \\
2000 & Margaret Jane Kidnie $^{14}$ & Oxford UP & 26 \\
\hline
\end{tabular}

reader to perceive Arruntius to be removed from the main action. Furthermore, the modern edition no longer reflects the format of the original, whose printing Jonson likely oversaw. ${ }^{15}$

Having neither a prompt copy of the play nor an eyewitness account of that particular scene (nor any other), it is impossible to know what Jonson intended. One possibility is that the actor playing Arruntius speaks all of his lines as asides. Another possibility is that he addresses the audience semi-directly. Finally, he could speak only eight of the lines as asides, and the rest as regular speech. The last option perhaps fits best the typography of the quarto and folio. With respect to the editing of Arruntius's asides, my own view is that when there is virtually no difference between the quarto and folio, the modern edition should reproduce the format of the original texts. Recently, Mark Bland notes that "replacing Jonson's practices with our own" could lead to "a cumulative misconstruction of the original meaning."16 His subject is Jonson editing in general, but his critique is applicable to Sejanus in particular.

In act 3, Arruntius simultaneously addresses Tiberius and the Senators. ${ }^{17}$ The act is divided into three distinctive sections:

Lines 1-153 The lead-up to Silius's trial

Lines 154-339 The trial itself, culminating in Silius's suicide

Lines 340-end The aftermath of Silius's trial; Cordus's trial

Arruntius ceases to speak in asides at 3.141 just as Silius's trial begins. Throughout his friend's trial, he criticizes Tiberius openly. In so doing, Arruntius practices a form of parrhesia. ${ }^{18}$ The portrait of Arruntius as a parrhesiastes corresponds to Tacitus's description of the historical figure. According to Tacitus, it was Arruntius's 
unfettered criticism of Tiberius's handling of Augustus's funeralhis assertion that Tiberius ought to parade the "titles of the laws by [Augustus] ordained, and the names of the nations by him vanquished" before Augustus's body that caused him to be hated by Tiberius. ${ }^{19}$ Arruntius further "offended" the newly crowned Tiberius by "using speeches not unlike unto Pollio." ${ }^{20}$ Additionally, Tacitus writes that it was well-known among the patricians that Augustus considered Arruntius to be his ideal successor, declaring that Arruntius was "not unworthy, and if occasion were given, would venter for it." ${ }^{21}$ Finally, by being "wealthy, bold, learned, and in reputation with all men," ${ }^{\prime 22}$ Arruntius reminded Tiberius of his failings.

Praise and flattery are wholly missing in Arruntius's addresses to Tiberius. He is not particularly interested in amending Tiberius's character; rather, he seeks to be as loud, obnoxious, and offensive to the presiding authority as possible. Various characters observe and interpret Arruntius's outbursts. According to Sejanus's spies, Arruntius's loquaciousness indicates a lack of political prudence: "[t]ut, hee's not yet / Look'd after, there are others more desir'd, / That are more silent" (2.407-9). The Germanicans agree with that assessment. On several occasions, they tell Arruntius to hold his "peace" (1.541) and to "check [his] passion" (1.547). As for Sejanus, there is use to be had in Arruntius's rants: they divert attention from Tiberius's plots. Sejanus therefore treats Arruntius as his unwitting aide. By allowing Arruntius the freedom to air his discontentment, Sejanus hopes to lull the Germanicans into a state of complacency:

The course must be, to let 'hem still swell up,

Riot, and surfet on blind fortunes cup;

Give 'hem more place, more dignities, more stile,

Call 'hem to court, to senate: in the while,

Take from their strength some one or twaine, or more

Of the maine Fautors.

$(2.260-65)$

Sejanus reiterates his strategy to Tiberius when the latter announces his intention to destroy Arruntius. Allow Arruntius the freedom to speak his mind, Sejanus advises Tiberius: 
By any meanes, preserve him. His franke tongue Being lent the reines, will take away all thought Of malice, in your course against the rest. We must keep him to stalke with.

By allowing Arruntius to speak out against him, Tiberius will be able to prove to the Senate that he is, as he claims, a tolerant ruler who embodies "modestie," "wisedome," "innocence," "meeknesse," and "pietie" (3.143-46).

\section{Public Discourse and Interpretive Communities}

Arruntius's scrutiny of the speeches of the judge, jury, prosecutor, and defendant teaches the audience to be critical of the law in action. His close reading also frames our perception of the legal action. John Sweeney makes the excellent observation that "all but six of the nearly six hundred lines spoken in Act I are delivered in the presence of the Germanicans and are, therefore, subject to their judgment. ${ }^{\prime 23}$ Despite the numerous occasions on which characters speak before groups, or within groups, in reading after reading, critics tend to privilege soliloquies over conversation, major speeches over minor ones. What if that paradigm is inverted so that more attention is given to the speeches of secondary characters?

Silius's trial is formulaic. It begins with a denunciation, the recitation of fama, the announcement of the accusation, the defendant's arguments, the sentencing, and the determination of punishment. We find this sequence of events in Tacitus-and also in standard books on Roman law. What is new, and curious, about the scene is Jonson's incorporation of para-legal discourse: the commentary of bystanders who are present before, during, and after the trials, with the legal discourse. When Arruntius complains aloud, he draws others into that discursive protest: he creates a critically interpretive community.

In act 3, Arruntius engages in eleven separate conversations with several people including Gallus, Cotta, Sabinus, and Lepidus. Arruntius dominates the soundscape. The public discourse achieved through Arruntius's conversations linguistically disrupts 
the flow of Tiberius's power. Two of these interludes are particularly relevant. Let us take a look.

The first instance of group analysis occurs just before the trial scene. After Tiberius declares to the Senate that he wishes his power to be "re-confer'd / Upon the Consuls, or some other Roman" (3.115-16), Sabinus, Gallus, and Arruntius analyze Tiberius's speech as a group. Each character concludes that Tiberius is manipulating the Senate:

Sabinus. Why, this doth render all the rest suspected!

Gallus. It poysons all.

Arruntius. O, do' you taste it then?

Sabinus. It takes away my faith to any thing

He shall hereafter speake.

Arruntius.

I, to pray that,

Which would be to his head as hot as thunder,

('Gainst which he weares that charme) should but the court

Receive him at his word.

Gallus.

Hear.

The addition of Gallus's agreement is a significant detail. It shows that Arruntius's criticism of Tiberius has spread beyond his immediate circle of associates. Gallus is an impartial observer; he has never before appeared on stage. Yet through his conversation with Arruntius and the others, Gallus comes to be convinced of Tiberius's insincerity.

The second instance of public discourse occurs at the end of the act. In this interlude, Arruntius, Sabinus, and Lepidus discuss the burning and censorship of Cordus's books.

Arruntius. Let 'hem [Cordus's books] be burnt! O, how ridiculous Appears the Senate's brainlesse diligence,

Who thinke they can, with present power, extinguish

The memorie of all succeeding times!

Sabinus. 'Tis true, when (contrarie) the punishment

Of wit, doth make th'authoritie increase.

Nor doe they ought, that use this crueltie

Of interdiction, and this rage of burning; 
But purchase themselves rebuke, and shame, And to the writers an eternall name.

Lepidus. It is an argument the times are sore,

When vertue cannot safely be advanc'd;

Nor vice reproov'd.

Arruntius. I, noble Lepidus,

Augustus well foresaw, what we should suffer,

Under Tiberius, when he did pronounce

The Roman race most wretched, that should live

Between so slow iawes, and so long a bruising.

In this conversation, the characters persuade each other of the righteousness of their position. Each man clarifies and amplifies the other's words. The polyptoton in "burnt" and "burning" illustrates rhetorically their ideological agreement. Just as Sabinus extracts the root of Arruntius's word, so Lepidus extracts and elegantly rephrases Arruntius's "argument" against censorship. The men further signal their agreement in short, courteous phrases such as " "Tis true" or "noble Lepidus." In the course of the conversation, they inspire each other to invent new accusations against Tiberius. Hence, the interlude serves several functions: it strengthens the bonds of masculine fellowship, and it allows each man to expend his creative energy.

In his address to the readers, Jonson apologizes for the lack of a formal chorus. It is, Jonson explains, a result of the technical deficiencies of contemporary theater. ${ }^{24}$ But in place of the formal chorus, Jonson creates a pseudo-chorus who enacts the process of observation and evaluation, mirroring the audience's observation of the play. In Sejanus, the audience must determine for themselves whether the comments by the minor characters correspond, enhance, or detract from their own understanding of the action.

Silius's suicide provides a case in point. After he stabs himself, Varro and Arruntius shout out competing opinions:

[SIL.] Looke upon Silius, and so learne to die. VAR. O desperate Act! ARR. An honourable hand! 
For a moment, the attention of the audience or reader is divided. In both the quarto and folio, Varro and Arruntius's lines are squeezed into the same line as shown above. ${ }^{25}$ By balancing Varro's disapproval and Arruntius's praise into the same line, Jonson conveys visually what the audience might have heard aurally: two short exclamations of approximately the same number of syllables, voiced simultaneously. Whom do we listen to? Whose interpretation of the suicide is closest to our own? This temporary state of doubt is conducive for legal reasoning - on the part of the audience, if not the fictional Senate.

\section{Conclusion}

Arruntius is an important figure who speaks, and is heard, by others throughout the play. As an educated and satirical commentator, the character of Arruntius might stand for Jonson, as critics have sometimes argued, or for the intellectuals and writers engaged in political and legal commentary during the early Jacobean period. As a commentator of the trials of Silius and Cordus, Arruntius uses his blunt and honest speech to antagonize the authorities and to frame the audience's understanding of the legal event. The character of Arruntius reminds readers that more often than not, the point of interest of trials is not their outcome, but the action of the community observing trials. Jonson's play does not only recreate a historical event-the rise and fall of Sejanusbut shows how others view, gloss, and interpret that event.

University of Southern California

\section{NOTES}

In writing this essay, I have benefited from the comments by Rebecca Lemon, Heather James, Joseph A. Dane, the readers of the Ben Jonson Journal, and the participants of "The Theater of Law" panel at the 13th Annual Conference of the Association for the Study of Law, Culture and Humanities (March 2010).

1. The play was first performed by the King's Men in 1603. Jonson revised and published the play two years later (London: George Eld for Thomas Thorpe, 1605). 
2. Margaret Jane Kidnie, "Notes to Page 117," Sejanus His Fall, in The Devil Is an Ass and Other Plays (Oxford: Oxford University Press, 2000), 457.

3. Ibid.

4. David Riggs, Ben Jonson: A Life (Cambridge, MA: Harvard University Press, 1989), 100.

5. Ben Jonson, Sejanus, His Fall, ed. C. H. Herford and Percy Simpson, vol. 4 (Oxford: Clarendon, 1954), 327-486. All subsequent citations will come from this edition, and will be given in the text parenthetically.

6. Marvin Vawter, "The Seeds of Virtue: Political Imperatives in Jonson's Sejanus," Studies in the Literary Imagination 6.1 (1973): 41-60. Vawter argues that "while the Germanicans continually talk of their nobility and their exalted ancestry, they have forgotten what is incumbent on nobility in a world that cries out for the action and valor of good men" (47), and that Jonson's play supports the tragic consequences of political stoicism as articulated by Jean Bodin, who attacks Neo-Stoics as those who "insulate themselves with private virtue and allow history its own ineluctable force" (55).

7. Richard Grenewey, The Annales of Cornelius Tacitus: The Description of Germanie (London: 1598), Sig. M4 ${ }^{\mathrm{r}}$. All quotations from Tacitus's Annals will come from this edition.

8. A similar point has been made recently by Sean McEvoy in Ben Jonson: Renaissance Dramatist (Edinburgh: Edinburgh University Press, 2008). McEvoy observes that modern editions "mark far more of these often sarcastic exclamations [Arruntius's comments during the trial of Cordus] as asides or lines to be addressed to just one character than Jonson did in the 1616 Folio" (39), but does not expand on the significance of this observation.

9. The eight asides are:

(1) ARR. Well acted, Caesar. (3.105, quarto Sig. F1 ${ }^{\mathrm{r}}$, folio Sig. Kk2 ${ }^{\mathrm{v}}$ )

(2) ARR. Laugh Fathers, laugh: Ha' you no spleens about you? (3.112, quarto Sig. $\mathrm{F}^{\mathrm{r}}$, folio Sig. Kk2 ${ }^{\mathrm{v}}$ )

(3) ARR. Laugh on, still. (3.117, quarto Sig. F1 ${ }^{\mathrm{v}}$, folio Sig. Kk2v $)$

(4) ARR. Finely maintained; good still. (3.128, quarto Sig. F1 ${ }^{v}$, folio Sig. $\mathrm{Kk}^{\mathrm{v}}$ )

(5) ARR. Ah! Are you there, to bring him of? (3.132, quarto Sig. F1 ${ }^{v}$, 1616 F, Sig. Kk2v $)$

(6) GAL. He comes about. / ARR. More nimbly then Vertumnus. (3.135-6, quarto Sig. F1 ${ }^{\mathrm{v}}$, folio Sig. Kk3 ${ }^{\mathrm{r}}$ )

(7) ARR. You must, and will Sir. We do know it. (3.141, quarto Sig. F1 ${ }^{v}$, Sig. $\mathrm{Kk}^{\mathrm{r}}$ ) 
(8) ARR. Where is't? / The Prayer's made before the Subject. (3.141, quarto Sig. F1 ${ }^{\mathrm{v}}$, folio Sig. $\mathrm{Kk}^{\mathrm{r}}$ )

10. G. A. Wilkes, ed., The Complete Plays of Ben Jonson, (Oxford: Oxford University Press, 1982) is not included in this list because it is based on the Herford and Simpson edition. W. F. Bolton's edition of Sejanus his Fall (London: Ernest Benn, 1966) is excluded for the same reason. Despite the criticism which the Herford and Simpson Oxford edition (1925-52) has received recently, it remains one of the few twentieth-century editions to reproduce exactly the look and typography of the quarto and folio in this particular act.

11. Jonas A. Barish, ed., Ben Jonson: Sejanus (New Haven: Yale University Press, 1965).

12. Johanna Procter, ed., The Selected Plays of Ben Jonson, vol. 1 (Cambridge: Cambridge University Press, 1989).

13. Philip J. Ayres, ed., Sejanus His Fall (Manchester, Manchester University Press, 1990).

14. Margaret Jane Kidnie, ed., Sejanus His Fall, in The Devil Is an Ass and Other Plays (Oxford: Oxford University Press, 2000).

15. John Jowett, "Jonson's Authorization of Type in Sejanus and Other Early Quartos," in W. Speed Hills, ed., New Ways of Looking at Old Texts: Papers of the Renaissance English Text Society, 1985-1991 (New York: Medieval \& Renaissance Texts \& Studies, 1993), argues that "Jonson was the editor of his own texts, and editorial treatment of his texts should do justice to him in that capacity as well as in the role of pure author" (186). Ayres in his "Introduction" to Sejanus also points out that the paucity of errors in the quarto suggests that Jonson personally oversaw the printing of the work: "[v]ery few errors were made, even in Jonson's copious marginal notes, and most of those were put right in proof, a testimony to the care of [George] Eld and of Jonson, who not only presented his printer with a scrupulously prepared fair copy but clearly supervised the printing process itself, altering in the proof tiny details that to a printer could hardly seem to need changing" (2).

16. Mark Bland, "Ben Jonson and the Legacies of the Past," Huntington Library Quarterly 67.3 (2004): 395.

17. The importance of the trial scene has been noted by critics; Brian Woolland, "Sejanus his Fall: Does Arruntius Cry at Night?" in Jonsonians: Living Traditions (Aldershot: Ashgate, 2003), 30, writes that "Jonson's decision to stage a public suicide at the exact centre point of the play is hugely significant." Woolland notes that the "historical Silius did commit suicide (Tacitus, Annals, IV.xix: "Silius anticipated the impending condemnation by a voluntary end") but not in the Senate." 
18. Act 3 is not the only opportunity for Arruntius to engage in parrhesia. Despite the presence of spies, and the knowledge that he is targeted by Tiberius and Sejanus, Arruntius does not censor himself. Arruntius declares within ear-shot of Sejanus's spies if Sejanus were to plot the deaths of the "brave issues of Germanicus" (1.249), he would "cleave him down from head to heart" with his sword (1.254). After Sabinus warns him that he is "observed" by Sejanus's agents (1.258), Arruntius retorts: "Death! I dare tell him so, and all his spies" (1.259). According to the stage directions, Arruntius should then "turn to Sejanus's clients" and taunt them with the following words: "You, sir, I would, do you look? And you!" (1.259). The two spies, Satrius and Natta, would later remark that unlike the other Germanicans who have "growne exceeding circumspect, and wary," only Arruntius continues to speak critically of Sejanus and Tiberius because-to quote Satrius-Arruntius is a man who "[c]annot contain himselfe" (2.407).

19. Grenewey, Annales, Sig. A2 ${ }^{\mathrm{v}}$.

20. Ibid., Sig. A $4^{\mathrm{r}}$.

21. The other candidates considered as successors by Augustus were Asinius Gallus and Marcus Lepidus. Augustus is quoted as saying that Gallus would be unsuitable to be his successor because he was "greedy to lay hold on it" (Sig. A4 ${ }^{\mathrm{r}}$ ), and Lepidus "was for his sufficiency able, but would refuse" (Sig. A4 ${ }^{\mathrm{v}}$ ). Regarding Lepidus, Tacitus says that he was "a grave and wise man who altered into the better many things, which others by cruel flattery had ordained: which he did with such moderation, that he kept in, with Caesar [i.e. Tiberius] in no less favor than authority" (Sig. $\mathrm{H6}^{\mathrm{v}}$ ).

22. Grenewey, Annales, Sig. A4 ${ }^{\mathrm{r}}$.

23. John G. Sweeney III, "Sejanus and the People's Beastly Rage," English Literary History 48.1 (1981): 69.

24. In his address "To the Readers," Jonson obviates criticism against his breach of classical rules of drama by admitting that his play lacks a chorus. Expanding this point, and indirectly defending his dramatic vision, Jonson reminds the reader that the same difficulty which prevents him from incorporating a chorus also hinders his contemporaries: "[a]s also in the want of a proper Chorus, whose Habite, and Moodes are such, and so difficult, as no any, whome I have seene since the Auntients, (no not they who have most presently affected Lawes) have yet come in the way off" (p. 350). Thus, Jonson elides the creation of a proper Greek chorus because of it entailed complications in costuming and choreography. "Habite" contains the sense of clothing, costuming, and "Moodes," the songs.

25. See Sig. $\mathrm{F} 4^{\mathrm{r}}$ in the quarto, and Sig. $\mathrm{Kk} 5^{\mathrm{r}}$ in the folio. 